\title{
A tale of conquest and crisis: invasion history and status of the American mink (Neovison vison) in Iceland
}

\author{
ROBERT A. STEFANSSON, ${ }^{1}$ MENJA VON SCHMALENSEE, ${ }^{1,2}$ JAKUB SKORUPSKI ${ }^{3}$
}

\author{
West Iceland Nature Research Centre, Hafnargotu 3, 340 Stykkisholmur, Iceland, e-mail: robert@nsv.is \\ Faculty of Life and Environmental Sciences, University of Iceland, Sturlugata 7, 101 Reykjavík, Iceland \\ Department of Ecology and Environmental Protection, Institute for Research on Biodiversity, Faculty of Biology, University of Szczecin, \\ Wąska 13, 71-415 Szczecin, Poland
}

Keywords climate change, distribution, fur farming, invasive species, Mustela vison, population management

Abstract Invasive alien species are among the major drivers of biodiversity loss, being destructive to native ecosystems, and human economy and well-being. Despite their severe negative impact, tracking the paths of biological invasions and distribution dynamics of invasive species, as well as assessing the scope and character of their interactions with resident species and ecosystems, can be difficult. An interesting case is the naturalization of the American mink in Iceland, with subsequent intensive culling and accurate registration of the number of mink killed by year and area, providing information on mink's distributional history. Additionally, the Icelandic ecosystem is relatively simple compared to other areas within the non-native range of the American mink. The species was introduced to Iceland in 1931 for commercial fur farming. Escapees spread and multiplied in the following decades. A bounty system for culling was established early, but was unable to halt population growth and the spread of the species. Hunting statistics seem to reflect actual changes in population size and show that population density kept on increasing for three decades after the mink had colonised all suitable habitats. After 2003, the numbers show a rapid $>60 \%$ decrease, probably at least in part caused by climate change influencing the marine food web. The American mink seems to have had a negative impact on some bird and freshwater fish populations. The case of the invasive American mink in Iceland improves our understanding of biological invasions, and aids in organizing eradication programmes or control of the species.

\section{Historia podboju i kryzysu: inwazja oraz obecny status norki amerykańskiej (Neovison vison) na Islandii}

Słowa kluczowe gatunek inwazyjny, hodowla zwierząt futerkowych, Mustela vison, rozprzestrzenienie, zarządzanie populacją, zmiany klimatu

Streszczenie Obce gatunki inwazyjne uznane zostały za jedną z głównych przyczyn spadku bioróżnorodności w skali globu, gdyż są one destrukcyjne nie tylko dla ekosystemów rodzimych, ale również dla gospodarki i dobrobytu społeczeństwa. Pomimo ich negatywnego i wielkoskalowego oddziaływania, w wielu przypadkach śledzenie przyczyn inwazji biologicznych oraz dynamiki 
rozprzestrzenienia obcych gatunków inwazyjnych, jak również ocena charakteru i zakresu ich interakcji z gatunkami i ekosystemami rodzimymi, jest trudne. Ciekawym przypadkiem jest naturalizacja norki amerykańskiej na Islandii, w następstwie której prowadzono szeroko zakrojoną akcję eradykcji ze szczegółowym rejestrem liczby zwierząt zabitych w danym roku i na danym obszarze, dokumentującym historyczne rozmieszczenie gatunku na wyspie. Dodatkowo, struktura ekosystemu Islandii ma charakter uproszczony, w porównaniu z innymi obszarami zajętymi przez ten inwazyjny gatunek. Norka amerykańska została sprowadzona na Islandię w celach hodowlanych (pozyskiwanie futer), we wczesnych latach 30. ubiegłego wieku. W kolejnych dziesięcioleciach dochodziło do ucieczek i reprodukcji w środowisku naturalnym wyspy. System dopłat dla myśliwych odławiających norki, wprowadzony już w kilka lat po introdukcji, nie powstrzymał wzrostu liczebności, ani nie zmniejszył zasięgu gatunku. Statystyki łowieckie zdają się odzwierciedlać rzeczywiste zmiany w wielkości populacji oraz wskazywać, że jej zagęszczenie wzrastało jeszcze w ciągu trzech dekad od momentu skolonizowania przez norkę amerykańską wszystkich zdatnych siedlisk. Po roku 2003 nastąpił gwałtowny, ponad $60 \%$ spadek liczebności populacji gatunku, przynajmniej częściowo spowodowany zmianami klimatu, wpływającymi na morskie sieci troficzne. Norka amerykańska ma zapewne negatywny wpływ na populację niektórych ptaków i słodkowodnych ryb na Islandii. Przypadek inwazji norki amerykańskiej na Islandii dostarcza cennej wiedzy w zakresie inwazji biologicznych oraz planowania programów kontroli lub eradykacji tego gatunku.

\section{Introduction}

Invasive alien species are one of the major drivers of biodiversity loss, being destructive not only to native biota, but also to human economy and well-being (Mooney 2005; Pimentel et al. 2005; Reaser et al. 2007). They can have dramatic effects on native ecosystems, disrupt their dynamics and cause devastating decline in populations of indigenous species, sometimes even their extinction (Clout \& Veitch 2002; Reaser et al. 2007).

The American mink (Neovison vison) is a well-known invasive predator. It is a generalist, semiaquatic mustelid, which can forage both on land and in water. It mostly occupies coastal rocky shores, wetlands and the banks of rivers and lakes (Dunstone 1993). Being very opportunistic in food choice, it can easily take advantage of changing accessibility and fluctuations in prey populations. Therefore, its diet tends to reflect local prey availability at a given time (Gerell 1967; Birks \& Dunstone 1985; Previtali et al. 1998; Sidorovich 2000, Schuttler et al. 2008; Magnusdottir et al. 2012). The American mink is native to Canada and U.S.A. (Larivière 1999). The species was introduced to Europe in the 1920s, for fur farming (Dunstone 1993). Accidental escapes from farms and in some cases intentional release resulted in naturalization of the American mink in many countries throughout the world. In almost every country to which the species was brought for fur farming, it was observed in the wild within a few years from the establishment of the first farms (Dunstone 1993; Bevanger \& Henriksen 1995; Bonesi \& Palazòn 2007). The American mink is now widespread in mainland Europe, the British Isles (Bonesi \& Palazòn 2007), Iceland (von Schmalensee 2010), Russia (in both its European and Asian parts), Kazakhstan, as well as the southern tip of South America (Mitchell-Jones et al. 1999; ISSG 2011; Fasola et al. 2011; Davis et al. 2012; Global Invasive Species Database 2016). The American mink is associated with a number of serious ecological problems in its non-native range, resulting from predation on and competition with native fauna. It is considered one of the 100 most invasive species in the world (DAISIE 2011), and one of the two worst invasive mammals in Europe when it comes to negative environmental impact (Nentwig et al. 2010; Kumschick et al. 2015 (Appendix S1)). 
The arrival of the American mink into the Icelandic ecosystem is in many ways interesting. In terms of species richness and abundance, the country is quite unlike other areas within the non-native range of the American mink, mostly because of its insular character (Magnusdottir et al. 2012). Species diversity is low with a total of nine terrestrial mammal wildlife species, only two of them of consequence to the mink; the Arctic fox (Vulpes lagopus), being the only other abundant terrestrial mammal predator (Unnsteinsdottir et al. 2016) and the wood mouse (Apodemus sylvaticus), as the only abundant rodent (Unnsteinsdottir \& Hersteinsson 2009). In addition, the country has no reptiles or amphibians in the wild (von Schmalensee 2010) and trophic terrestrial networks are therefore often relatively simple and well defined. Thus, upon introduction to the country, the mink possibly entered a mostly unoccupied niche.

It can be difficult to understand the distribution dynamics of invasive alien species and track the paths of biological invasions. It is also often challenging to assess the scope and character of their interactions with resident species and ecosystems (Parker et al. 1999; Byers et al. 2002). Therefore, available information on this subject is valuable, as it can deepen our understanding of invasive species, and to what extent management is needed. Iceland's ecological conditions provide an excellent basis for ecological research on biological invasions (Skirnisson \& Petersen 1980; Skirnisson et al. 2004; Meltofte 2013; Magnusdottir et al. 2014). In this context, we review the introduction, naturalization and spread of the American mink in Iceland. Furthermore, investigate the literature of the recorded impact of the mink on the Icelandic ecosystem, and discuss the influence of mink farms and mink management in the country.

\section{Mink farming and its relation to the feral mink population}

The first Icelandic mink farms were established in 1931 in the southwest part of the country. The initial mink imported for fur farming were purchased from farmers in Norway and were descendants of mink caught in the Mississippi valley in mid North America. They were of the two subspecies $N$. vison letifera and $N$. vison lacustris, which were smaller and had a poorer pelt quality than mink farmed later on. They were at an early stage in the process of domestication and did not differ significantly from their wild North American ancestors. All mink farmed in Iceland in the years 1931-1937 were of these breeds, but other mink breeds were imported subsequently (Øvrebro 1931; Holmjarn 1947; Holmjarn 1948; Skirnisson \& Petersen 1980; Hall 1981; Bevanger \& Ålbu 1986).

Mink farms operated from 1931-1952, when farms were closed due to a complete ban on mink farming, in part due to mink escaping and spreading. In the years 1953 to 1969 no mink farming took place in Iceland, but commenced again in 1970 with a completely new stock after the ban was lifted. There was a dramatic increase in the number of farms and farmed mink after 1985, but in the years 1990-2013 the size of the national stock of farmed mink was relatively stable between 30 and 40 thousand animals in most years. However, in 2014-2015, the number of farmed mink increased to around 50 thousand animals (Fig. 1) (Statistics Iceland 2016). In the 1980s, the farms were distributed around most of the lowlands of Iceland, but in recent years, their distribution has become patchier, with fewer larger farms (Fig. 2). 


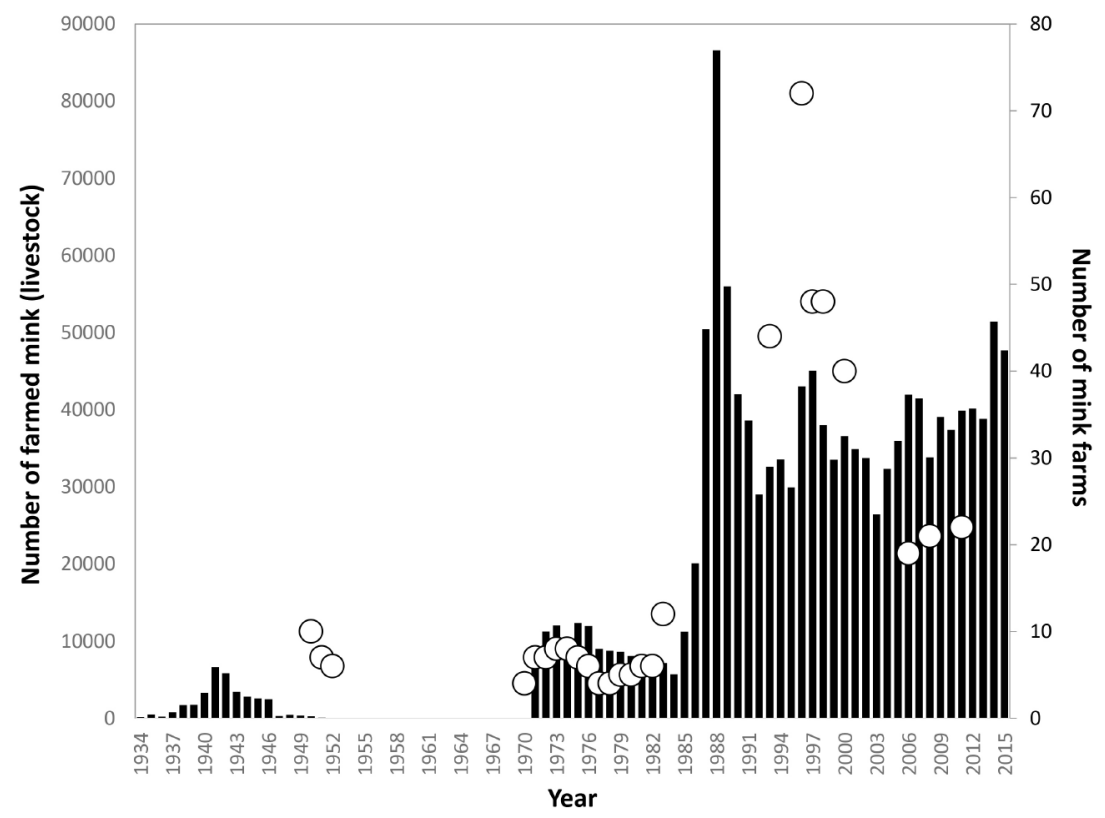

Figure 1. The number of farmed mink (columns) and mink farms (open circles) in Iceland from 1934-2015 (Statistics Iceland 2016)

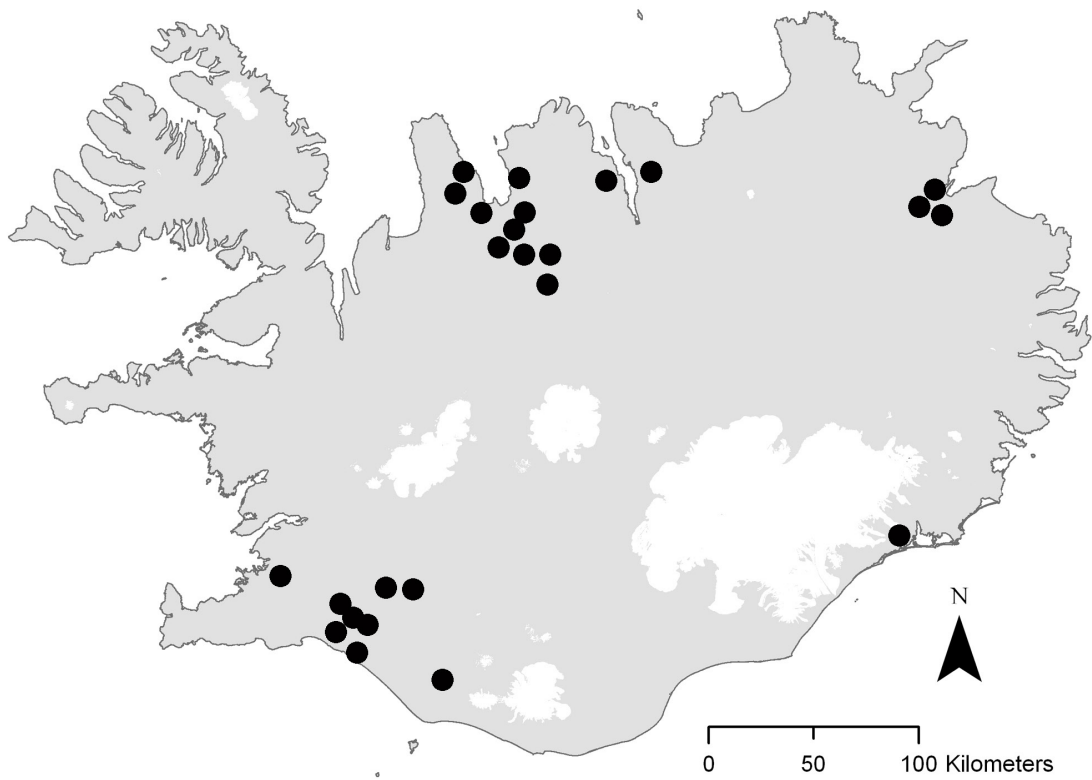

Figure 2. Locations (dots) of American mink farms in Iceland in 2012 (Gunnar Gudmundsson, The Farmers Association of Iceland, pers. comm. 2014) 
It is of special interest that the current feral mink population is most likely descended from the original Mississippi breeds (Skirnisson 1993). Mink seem to have escaped the farms almost immediately as the industry began, and all feral mink caught in the wild in the years 1939-1948 were descendants of the mink farmed during 1931-1937 (Holmjarn 1948). Despite frequent escapes of farmed mink since farming began anew in 1970, external characteristics of feral mink in Iceland do not seem to have changed notably (Skirnisson 1989; Stefansson, unpubl. data). Extensive hybridization with mink breeds farmed later on is therefore unlikely, since the latter are easily recognizable by larger size, higher fur quality and in most cases a different colour. This is a very different situation compared to many other countries within the non-native range, where feral mink are not easily distinguished from farmed mink based on appearance alone. In Denmark, where thousands of feral mink are killed annually, wildlife scientists have doubted that any true feral population exists, because the "feral" population seems to be continuously supplemented by escapees from farms (Hammershoj et al. 2005; Pertoldi et al. 2013).

\section{Distributional history}

Mink escaped from the first farms in the southwest part of the country nearly instantly. The first field observations of escaped mink were made in 1932 in the vicinity of the first mink farms and the first mink den in the wild was found near Reykjavik in 1937 (Skirnisson \& Petersen 1980). The mink spread from there in two main directions (Fig. 3); one was to the east across the southern lowlands, but the spread stopped there, as the mink did not traverse the natural barrier of highlands, great glacial rivers and sand plains south and southeast of the Vatnajokull glacier. The other main direction of spread from southwest Iceland was north along the west coast, then the mink continued east along the north coast, and finally in the 1970s it came south along the east coast and colonised the southeast part of Iceland around 1975, thereby completing the circle around the island. In less than 40 years, mink had colonized all suitable lowlands of Iceland, including most of the coastline, rivers, lakes and even islands more than $10 \mathrm{~km}$ from the mainland by 'island hopping' (Skirnisson \& Petersen 1980; Bjornsson \& Hersteinsson 1991; Skirnisson et al. 2004). The accumulated minimum dispersal distance covered in these four decades was $700-800 \mathrm{~km}$. Therefore, the average minimum advance of the dispersal front was approximately $20 \mathrm{~km} / \mathrm{year}$ (Hersteinsson et al. 2012). The real dispersal distance travelled by the animals was almost certainly much longer. In comparison, the rate of expansion in Argentina, where mink was much more likely to meet competitors, varied between 5.53 and $9.00 \mathrm{~km} /$ year (Fasola et al. 2011).

It might be of consequence that the Arctic fox population in Iceland was at a historic low in the 1970s, during the time of the mink colonization (Palsson et al. 2016; Unnsteinsdottir et al. 2016). In some species, e.g. voles, there is a negative correlation between population density and the frequency of dispersing juveniles (Hanski 1999; Ims \& Andreassen 2005). It is unknown if mink dispersal is positively or negatively density-dependent. The lack of inter- and intra-species competition in the first decades of mink in Iceland may however have facilitated long-distance dispersal, as dispersing mink might not have had to settle for the first available uninhabited suitable habitat they came across, but had the opportunity to roam long distances without encountering competition, searching for the very best habitat on the way. A recent study showed that at low mink population density, maximum inferred dispersal distances were around $55 \mathrm{~km}$ for males and $40 \mathrm{~km}$ for females (Oliver et al. 2016). 


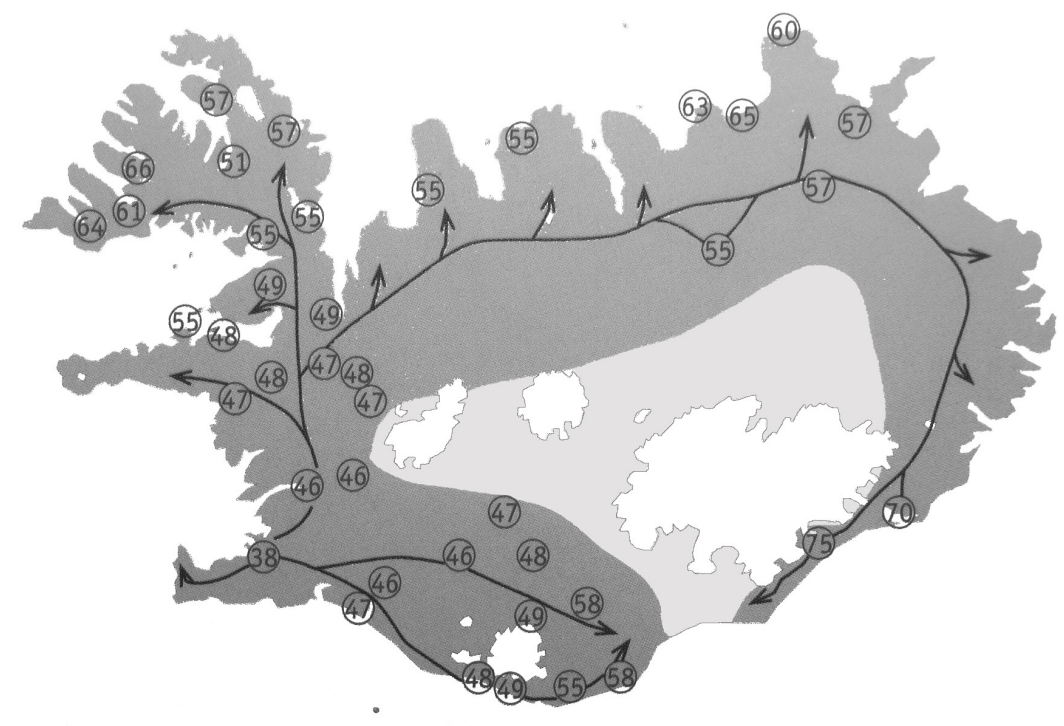

Figure 3. The distribution history of mink in Iceland. The arrows show the general direction of dispersal from the original source in the southwest. The numbers in circles represent the year of the $20^{\text {th }}$ century when the first mink was killed in that area. The white areas represents glaciers and the barren central highlands, where mink is practically absent (Skirnisson et al. 2004, reproduced from Skirnisson \& Petersen 1980)

\section{Environmental effects}

Within its non-native range, studies have shown devastating effects of American mink predation on small mammals (Macdonald \& Harrington 2003), birds (Craik 1995; 1997; Ferreras \& Macdonald 1999; Clode \& Macdonald 2002; Nordstrom et al. 2003; 2004; Banks et al. 2008), amphibians (Ahola et al. 2006) and fish (Heggenes \& Borgstrom 1988) as well as a negative effect on the European mink (Mustela lutreola) through competition and aggression (Maran et al. 2016).

As the mink population expanded and became firmly established in Iceland, a negative impact on several native species emerged. With the Arctic fox as the only mammalian predator in the country for the past 10 thousand years, some bird species in Iceland had adapted to the presence of the fox by nesting in dense colonies on islands, in cliffs and other places inaccessible to the fox (Hersteinsson 1990; 1999). With the arrival of the semi-aquatic American mink, these places were no longer secure from predation. Generally, it is well known that introduced mammalian predators can have a dramatic impact on breeding colonies of birds, especially ground-nesting seabirds (Blackburn et al. 2004) and Iceland proved to be no exception. The mink is believed to have had negative impact on colonies of Atlantic puffin (Fratercula arctica) (Gislason 1995; Petersen 1982; Asgeirsson 2011) and the black guillemot (Cepphus grylle) (Petersen 1979; Johannsson \& Gudjonsdottir 2007). It affected the distribution and perhaps number of ducks (Gardarsson 1979; Einarsson et al. 2004; Einarsson et al. 2006) and has regularly caused damage in common eider (Somateria mollissima) breeding colonies (Doughty 1979; Jonsson 2001). It also probably caused declines in the horned grebe (Podiceps auritus) population (Nielsen 1998) 
and last, but not least, mink predation in conjunction with habitat destruction by wetland drainage is believed to have caused the extinction of the water rail (Rallus aquaticus) in Iceland in the 1970s (Skarphedinsson 1998).

Information on the effects on fish is very limited, but unconfirmed claims of farmers and fishermen about changes in the distribution and in some cases the disappearance of local populations of Arctic charr (Salvelinus alpinus) indicate negative impact in smaller streams, similar to results from a Norwegian study (Heggenes \& Borgstrøm 1988).

\section{Mink management}

Icelanders quickly realized the necessity of limiting damage caused by feral mink. The first law regarding mink farms' security and hunting of feral mink was passed in 1937, and the first feral mink was killed in 1938. A year later, the Icelandic authorities started hiring hunters and commenced a bounty system (Hannesson 1956). The first law clearly stating that mink should be eradicated, was passed in 1949. In 1958, the Wildlife Management Institute was established. Despite its effort, mink continued to spread and in the Wildlife Act passed in 1994, mink management no longer aimed for eradication. Instead, the goal was to limit negative effects of mink. Since 2004, hunters and landowners no longer need a hunting certificate to kill mink, as long as they use legal hunting methods.

Two main methods have been used for hunting mink in Iceland. One is the use of trained scent dogs who find dens and aid in flushing out the mink, which is shot or killed by the dogs. The other method is death traps of various kinds (Hersteinsson 1999; Brynjolfsson 2001; von Schmalensee et al. 2013). Dogs have mostly been used in spring and summer, but traps are set in all seasons. The majority of the catch has been obtained in May and June.

The cost of mink hunting has been undertaken by both the Icelandic state and the municipalities. At first, the state contributed the majority, but in recent years, it has been split in equal shares. The bounty to date for each mink is 3000 ISK (25€; exchange rate 1 December 2016) and hired hunters are usually paid a low salary per hour in addition to driving expenses. The bounty itself has always been a considerable part of the salary for mink hunting. Most municipalities pay five times more for pregnant or lactating females in April and May as for other mink, thereby encouraging hunters to kill mink before birds start nesting in spring.

The application of extensive and large-scale culling measures for decades, with bounty hunting and local authorities employing mink hunters has never been close to obtaining countrywide eradication. Feral mink is still present in suitable mink habitats. Nevertheless, culling in and around important bird areas in spring has probably prevented local population collapses in some prey species, and has therefore been important for wildlife protection.

In the years 2007-2009, the Icelandic government funded an experimental mink eradication project in two large areas $\left(1300\right.$ and $\left.3900 \mathrm{~km}^{2}\right)$, with the objective to evaluate if a countrywide eradication would be feasible, and estimate its cost. Although mink numbers went considerably down in the two areas due to increased hunting effort and other factors, eradication was not successful and the project did not reach its objectives. Valuable lessons concerning mink eradication and management in general were however learned, which might aid in future organisation of mink management (Hersteinsson et al. 2012). Were mink to be eradicated in Iceland, the closure of all mink farms would be vital, as mink escaping from farms would probably always threaten eradication success. 


\section{Population dynamics}

The size of the feral mink population in Iceland has never been estimated countrywide. However, hunting statistics have been kept since mink hunting began, with official supervision after 1958 when the Wildlife Management Institute was established. From that time, the available information include the number of bounties paid each year in each municipality (Hersteinsson 1999; von Schmalensee 2013).

Using the hunting bag as an index of population size, the mink population seems to have increased, with fluctuations, from the beginning until 2003 (Fig. 4). As mink had spread to all parts of the country by 1975, this implies that population density increased for three decades after mink had settled all lowland areas. After 2003, the number of paid bounties decreased dramatically, probably reflecting true population decrease, at least at large.

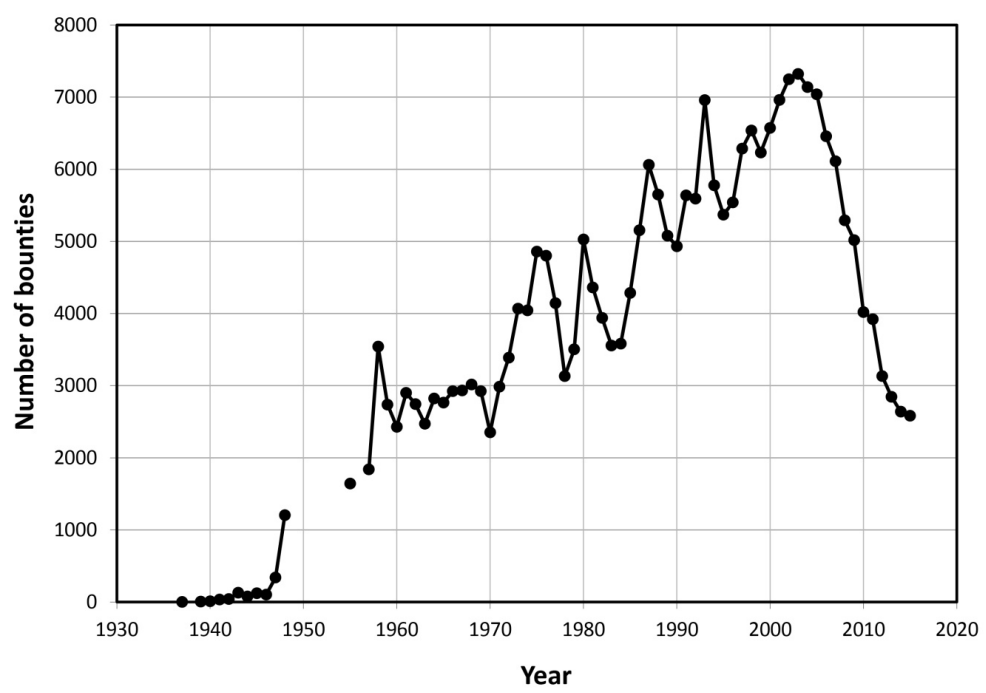

Figure 4. Number of bounties paid for mink killed in Iceland 1937-2015. The accumulated number of bounties is 266908 (data 1937-1957 from various sources; data 1958-2015 from The Environment Agency of Iceland)

The hunting statistics should provide a good indication on changes in mink population size, as the organization of mink hunting and hunting pressure has been relatively unchanged since the beginning (Hersteinsson et al. 2012). However, it is possible that the dramatic $>60 \%$ decline from 2003-2015, is somewhat exaggerated. Following an economic crisis in Iceland starting at the end of 2008, some municipalities decided to limit their payments to mink hunting by setting a maximum quota on the number of mink they would pay for each year. In those areas, this new arrangement began in the years 2009-2011. This change did not influence the hunting intensity in all cases, but in a few municipalities, it probably did. It is impossible to estimate the influence of this arrangement on the reduction in the mink hunting bag, but judging from direct communication with mink hunters and municipalities, it most likely explains merely a minor part of the observed crash in mink numbers. Hunters in general also claim that mink density in the last decade 
has been much lower than previously, supporting that the decline in the number of bounties reflects actual changes in population size.

The cause of the population decline is of course of great interest, as understanding what could influence the mink population so dramatically would aid in decision making concerning mink management. The crash coincided with widespread breeding failures of several Icelandic seabird species (Gardarsson 2006; Thrainsson et al. 2011), probably caused by less availability of their most important prey, the sandeel (Ammodytidae) (Bogason \& Lilliendahl 2009; Lilliendahl et al. 2013). The sandeel has crashed in many areas in the N-Atlantic, e.g. the North Sea, most likely because of climate change (Arncott \& Ruxton 2002). Sandeel is not a part of mink diet and seabirds are only a small part of it. Nevertheless, mink diet changed in the years 2001-2009 and it seems that climate change might have cascaded through the food web to the American mink, causing reduced access to optimal prey, thereby contributing to the reduction in population size (Magnusdottir et al. 2014).

A number of other factors might however also have contributed to the observed decrease. The Arctic fox population has been strong in recent years (Unnsteinsdottir et al. 2016), possibly contributing to the decline through indirect competition for food and mink harassment (Magnusdottir et al. 2014). A new type of controversial death-trap, killing mink by drowning, has been progressively applied for the last 15 years, increasing catches during winter and early spring when the population is at its smallest numbers and most vulnerable (von Schmalensee et al. 2013). Apart from climate change, fox disturbance and hunting, the possibility that pollutants, diseases or parasites are influencing the Icelandic mink population has not been ruled out.

\section{Conclusion}

Here we have reviewed the relatively well documented naturalization of American mink in Iceland. It shows that the Icelandic feral mink population seems to have descended mostly from the first mink to escape from captivity. In this case, a low propagule pressure of an invasive species was therefore sufficient to establish a very viable population. It is also worth noting, that the increase in population size for three decades after mink had occupied all lowlands strongly indicates that mink first settled in optimal habitats, later moving into more marginal habitats. Despite signs of climate change being involved, the population crash after 2003 is still not fully understood, which underlines the importance of research on and monitoring of invasive species, along with measurements of numerous factors in the natural environment, to be able to explain their population dynamics.

The example of the American mink invasion in Iceland proves the necessity of a comprehensive and holistic approach to the problem of mink invasions. Although hunting commenced early on in the invasion process, its intensity was not high enough to eradicate the population or stop the spread. The American mink is clearly difficult to manage and culling and eradication demands a considerable amount of work, skill and finance. This example shows the importance of pre-emptive measures when it comes to biological invasions, and the need to involve all relevant stakeholders when implementing strategies of management and eradication of invasive alien species (Genovesi 2005; Simberloff 2009; Skorupski 2016). 


\section{Acknowledgements}

We thank two anonymous reviewers for their constructive comments, which helped us to improve the manuscript.

\section{References}

Ahola M., Nordstrom M., Banks P.B., Laanetu N., Korpimaki E. 2006. Alien mink predation induces prolonged declines in archipelago amphibians. Proceedings of the Royal Society B-Biological Sciences, 273: $1261-1265$.

Arncott S.A., Ruxton G.D. 2002. Sandeel recruitment in the North Sea: demographic, climatic and trophic effects. Mar. Ecol. Prog. Ser., 238: 199-210.

Asgeirsson A. 2011. Breytingar og faersla lunda á sudursvaedi Breidafjardar. Fuglar, 8: 44-46.

Banks P.B., Nordstrom M., Ahola M., Salo P., Fey K., Korpimaki E. 2008. Impacts of alien mink predation on island vertebrate communities of the Baltic Sea Archipelago: review of a long-term experimental study. Boreal Environment Research, 13: 3-16.

Bevanger K., Ålbu Ø. 1986. Mink Mustela vison i Norge. Økoforsk Utredning, 6: 1-73.

Bevanger K., Henriksen G. 1995. The distributional history and present status of the American mink (Mustela vison Schreber, 1777) in Norway. Annales Zoologici Fennici, 32: 11-14.

Birks J.D.S., Dunstone N. 1985. Sex-related differences in the diet of the mink Mustela vison. Holarctic Ecology, 8 (4): 245-252.

Bjornsson T., Hersteinsson P. 1991. Minkar vid sunnanverdan Breidafjord [Mink in southern Breidafjordur Bay, W-Iceland]. Wildlife Management News, 7: 3-12.

Blackburn T.M., Cassey P., Duncan R.P., Evans K.L., Gaston K.J. 2004. Avian extinction and mammalian introductions on oceanic islands. Science, 24: 1955-1958.

Bogason V., Lilliendahl K. 2009. An initiation of sandeel monitoring in Iceland. Hafrannsoknir, 145: 36-41.

Bonesi L., Palazòn S. 2007. The American Mink in Europe: status, impacts, and control. Biological Conservation, 134: 470-483.

Brynjolfsson B. 2001. Veidiadferdir a mink a Islandi arid 1999 med serstakri aherslu a gildruveidar [Methods for mink hunting in Iceland in 1999, with an emphasis on trapping]. Skyrsla Veidistjoraembaettisins, p. 40.

Byers J.E., Reichard S., Randall J.M., Parker I.M., Smith C.S., Lonsdale W.M., Atkinson I.A.E., Seatedt T.R., Williamson M., Chornesky E., Hayes D. 2002. Directing research to reduce the impacts of nonindigenous species. Conservation Biology, 3: 630-640.

Clode D., Macdonald D.W. 2002. Invasive predators and the conservation of island birds: the case of American Mink Mustela vison and terns Sterna spp. in the Western Isles, Scotland. Bird Study, 49: 118-123.

Clout M.N., Veitch C.R. 2002. Turning the tide of biological invasion: the potential for eradicating invasive species. In: Turning the Tide: the Eradication of Invasive Species. International Conference on Eradication of Island Invasiveness. C.R. Veitch, M.N. Clout (eds.). IUCN Species Survival Commission. Gland, Switzerland and Cambridge, UK, pp. 1-3.

Craik J.C.A. 1995. Effects of North American mink on the breeding success of terns and smaller gulls in west Scotland. Seabird, 17: 3-11.

Craik C. 1997. Long-term effects of North American mink Mustela vison on seabirds in western Scotland. Bird Study, 44: 303-309. 
DAISIE 2011. Delivering Alien Invasive Species Inventories for Europe, www.europe-aliens.org. 100 of the worst (22.10.2016).

Davis E.F., Anderson Ch.B., Valenzuela A.E.J., Cabello J.L., Soto N. 2012. American Mink (Neovison vison) Trapping in the Cape Horn Biosphere Reserve: Enhancing Current Trap Systems to Control an Invasive Predator. Annales Zoologici Fennici, 49: 18-22.

Doughty R.B. 1979. Eider husbandry in the North Atlantic: trends and prospects. Polar Record, 122: 447-459.

Dunstone N. 1993. The Mink. T. \& A.D. Poyser Ltd. London. p. 323.

Einarsson A., Stefansdottir G., Johannesson H., Olafsson J.S., Gislason G.M., Wakana I., Gudbergsson G, Gardarsson A. 2004. The ecology of Lake Myvatn and the River Laxa: Variation in space and time. Aquatic Ecology, 38: 317-348.

Einarsson A., Gardarsson A., Gíslason G.M., Gudbergsson G. 2006. Populations of ducks and trout of the River Laxa, Iceland, in relation to variation in food resources. Hydrobiologia, 567: 183-194.

Fasola L., Muzio J., Chehébar C., Cassini M., MacDonald D.W. 2011. Range expansion and prey use of American mink in Argentinean Patagonia: dilemmas for conservation. European Journal of Wildlife Research, 57: 283-294.

Ferreras P., Macdonald D.W. 1999. The impact of American mink Mustela vison on waterbirds in the upper Thames. Journal of Applied Ecology, 36: 701-708.

Gerell R. 1967. Food selection in relation to habitat in mink (Mustela vison Schreber) in Sweden. Oikos, 18: 233-246.

Gardarsson A. 1979. Waterfowl populations of Lake Myvatn and recent changes in numbers and food habits. Oikos, 32: 250-270.

Gardarsson A. 2006. Recent changes in Icelandic cliff birds. Bliki, 27: 13-22.

Genovesi P. 2005. Eradications of invasive alien species in Europe: a review. Biological Invasions, 7: 127-133.

Gislason K.B. 1995. Thegar minkurinn nam land i Breidafjardareyjum og afleidingar thess. Breidfirdingur, 53: $53-58$

Global Invasive Species Database (2016) Species profile: Neovison vison. http://www.iucngisd.org/gisd/ speciesname/Neovison+vison (29.10.2016).

Hall E.R. 1981. The mammals of North America. Vol. 2. John Wiley and Sons, New York.

Hammershøj M., Pertoldi C., Asferg T., Møller T.B., Kristensen N.B. 2005. Danish free-ranging mink populations consist mainly of farm animals: Evidence from microsatellite and stable isotope analyses. Journal for Nature Conservation, 13: 267-274.

Hannesson E. 1956. Islenski villiminkurinn. Nokkur atridi ur aldarfjordungssogu minkanna her á landi. Visir, 6.06.1956.

Hanski I. 1999. Metapopulation Ecology. Oxford University Press, USA, pp. 328.

Heggenes J., Borgstrom R. 1988. Effect of mink, Mustela vison Schreber, predation on cohorts of juvenile Atlantic salmon, Salmo salar L., and brown trout, Salmo trutta L., in 3 small streams. Journal of Fish Biology, 33: 885-894.

Hersteinsson P. 1990. Eider farming and predator management in Iceland. Symposium: Managing predation to increase production of wetland birds. North Dakota, 15-17.08.1990.

Hersteinsson P. 1999. Methods to eradicate the American mink (Mustela vison) in Iceland. In: Proceedings of the Workshop on the Control and Eradication of Non-native Terrestrial Vertebrates. vol. 41. Environmental Encounters, Council of Europe Publishing, pp. 25-29.

Hersteinsson P., Stefansson R.A., von Schmalensee M. 2012. Tilraunaverkefni um svaedisbundna utrymingu minks $i$ Eyjafirdi og a Snaefellsnesi 2007-2009 A report to the Ministry for the Environment and Natural Resources. p. 58. 
Holmjarn H.J. 1947. Loddyra og sauðnauta pattur, -innflutningur loddyra til Islands. Thaettir um innflutning bufjar og karakulsjukdoma: 64-67. Rikisprentsmidjan Gutenberg, Reykjavík.

Holmjarn H.J. 1948. Svar við brefi hattvirtrar landbunadarnefndar nedri deildar Althingis, vidvikjandi frumvarpi til laga um utrymingu villiminka. Erindi til Althingis. Dagbok 268.

Ims R.A., Andreassen H.P. 2005. Density-dependent dispersal and spatial population dynamics. Proceedings of the Royal Society B-Biological Sciences, 272: 913-918.

ISSG 2011. Global Invasive Species Database (GISD). Invasive Species Specialist Group of the IUCN Species Survival Commission. http://www.issg.org/database (29.10.2016).

IUCN 2000. IUCN Guidelines for the Prevention of Biodiversity Loss Caused by Alien Invasive Species. Approved by the 51st meeting of the IUCN Council, Gland Switzerland, February 2000. https://portals.iucn.org/library/efiles/documents/Rep-2000-052.pdf (27.10.2016).

Jonsson J. 2001. Aedarfugl og aedarraekt a Islandi. Mal og mynd, Reykjavik, p. 528.

Johannesson J.H., Gudjonsdottir B. 2007. The effect of mink-predation on six monitored Black Guillemot colonies in Strandasysla, NW-Iceland. Natturufraedingurinn, 76: 29-36.

Kumschick S., Bacher S., Evans T., Markova Z., Pergl J., Pysek P., Vaes-Petignat S., van der Veer G., Vila M., Nentwig W. 2015. Comparing impacts of alien plants and animals in Europe using a standard scoring system. Journal of Applied Ecology, 52: 552-561.

Larivière S. 1999. Mustela vison. Mammalian Species, 608: 1-9

Lilliendahl K., Hansen, E.S, Bogason V., Sigursteinsson M., Magnusdottir M.L., Jonsson P.M., Helgason H.H., Oskarsson G.J., Oskarsson P.F., Sigurdsson O.J. 2013. Vidkomubrestur lunda og sandsilis við Vestmannaeyjar. Natturufraedingurinn, 83: 65-79.

Macdonald D.W., Harrington L.A. 2003. The American mink: the triumph and tragedy of adaptation out of context. New Zealand Journal of Zoology, 30: 421-441.

Magnusdottir R., Stefansson R.A., von Schmalensee M., Macdonald D.W., Hersteinsson P. 2012. Habitatand sex-related differences in a small carnivore's diet in a competitor-free environment. European Journal of Wildlife Research, 58: 669-676.

Magnusdottir R., von Schmalensee M., Stefansson R.A., Macdonald D.W., Hersteinsson P. 2014. A foe in woe: American mink (Neovison vison) diet changes during a population decrease. Mammalian Biology, 79: 58-63.

Maran T., Skumatov D., Gomez A., Põdra M., Abramov A.V., Dinets V. 2016. Mustela lutreola. The IUCN Red List of Threatened Species 2016: e.T14018A45199861.http://dx.doi.org/10.2305/IUCN.UK.20161.RLTS.T14018A45199861.en (22.10.2016).

Meltofte H. (ed.) 2013. Arctic Biodiversity Assessment. Status and trends in Arctic biodiversity. Conservation of Arctic Flora and Fauna. Akureyri.

Mitchell-Jones A.J., Amori G., Bogdanowicz W., Kryštufek B., Reijnders P.J.H., Spitzenberger F., Stubbe M., Thissen J.D.M., Vohralik V., Zima J. 1999. Atlas of European Mammals. T\&A D Poyser Ltd, London, p. 484.

Mooney H.A. 2005. Invasive Alien Species: A New Synthesis. Vol. 63. Scientific Committee on Problems of the Environment (SCOPE) Series. Island Press.

Nentwig W., Kuhnel E., Bacher S. 2010. A generic impact-scoring system applied to alien mammals in Europe. Conservation Biology, 24: 302-311.

Nielsen O.K. 1998. Hrun florgodastofnsins a Islandi [The collapse of the horned grebe population in Iceland]. In: Islensk votlendi; verndun og nyting. J.S. Olafsson (ed.). Haskolautgafan, Reykjavik, pp. 197-205. 
Oliver M.K., Piertney S.B., Zalewski A., Melero Y., Lambin X. 2016. The compensatory potential of increased immigration following intensive American mink population control is diluted by male-biased dispersal. Biological Invasions, 18: 3047-3061.

Øvrebro C. 1931. Minkavlens fremtid under de forandrede forhold. Norsk Pelsdyrblad, 5: 224-226.

Palsson S., Hersteinsson P., Unnsteinsdottir E.R., Nielsen O.K. 2016. Population limitation in a non-cyclic arctic fox population in a changing climate. Oecologia, 180: 1147-1157.

Parker I.M., Simberloff D., Lonsdale W.M., Goodell K., Wonham M., Kareiva P.M., Williamson M.H., Von Holle B., Moyle P.B., Byers J.E., Goldwasser L. 1999. Impact: toward a framework for understanding the ecological effects of invaders. Biological Invasions, 19: 3-19.

Pertoldi C., Rodjajn S., Zalewski A., Demontis D., Loeschke V., Kjaersgaard A. 2013. Population viability analysis of American mink (Neovison vison) escaped from Danish mink farms. Journal of Animal Science, 91: 2530-2541.

Petersen AE. 1979. Varpfuglar Flateyjar á Breidafirdi og nokkurra naerliggjandi eyja. Natturufraedingurinn, 49: 221-256.

Petersen AE. 1982. Sjofuglar. Rit Landverndar, 8: 15-60.

Pimentel D., Zuniga R., Morrison D. 2005. Update on the environmental and economic costs associated with alien-invasive species in the United States. Ecological Economics, 52: 273-288.

Previtali A., Cassini M.H., Macdonald D.W. 1998. Habitat use and diet of the American mink (Mustela vison) in Argentinian Patagonia. Journal of Zoology, 246: 482-486.

Reaser J.K., Meyerson L.A., Cronk Q., de Poorter M., Elrege L.G., Green E., Kairo M., Latasi P., Mack R.N., Mauremootoo J., O’Dowd D., Orapa W., Sastroutomo S., Saunders A., Shine C, Thrainsson S., Vaitu L. 2007. Ecological and Socioeconomic Impacts of Invasive Alien Species in Island Ecosystems. Environmental Conservation, 34: 1-14.

Schuttler E., Caracamo J., Rossi R. 2008. Diet of the American mink Mustela vison and its potential impact on the native fauna of Navarino Island, Cape Horn Biosphere Reserve, Chile. Revista Chilena de Historia Natural, 81 (4): 585-598.

Sidorovich V.E. 2000. Seasonal variation in the feeding habits of riparian mustelids in river valleys of NE Belarus. Acta Theriologica, 45 (2): 233-242.

Simberloff D. 2009. We can eliminate invasions or live with them. Successful management projects. Biological Invasions, 11: 149-157.

Skarphedinsson K. 1998. Keldusvinid - fornarlamb framraeslu og minks. In: Islensk votlendi; verndun og nyting, J.S. Olafsson (ed.). Haskolautgafan, Reykjavik, pp.193-196.

Skirnisson K. 1989. Uppbod a skinnum af islenskum villiminkum. Freyr, 85: 242-246.

Skirnisson K. 1993. Minkur. In: Villt islensk spendyr P. Hersteinsson, G. Sigbjarnarson (eds.). Landvernd \& Hid islenska natturufraedifelag, pp. 79-102.

Skirnisson K., Petersen Æ. 1980. Minkur. In: Villt spendýr Á. Einarsson (ed.). Rit Landverndar, 7, pp. 80-94

Skirnisson K., Stefansson R.A., von Schmalensee M. 2004. Minkur. In: Islensk spendyr P. Hersteinsson (ed.). Vaka-Helgafell, pp. 88-97.

Skorupski J. 2016. Nature conservation and invasion of the American mink (Neovison vison) in Poland a critical analysis. Sylwan, 160: 79-87.

Statistics Iceland 2016. Livestock and field crops. http://px.hagstofa.is/pxen/pxweb/en/Atvinnuvegir/Atvinnuvegir_landbunadur_landbufe/LAN10102.px (23.10.2016).

Thrainsson S.A., Baldursson S, Gardarsson A., Gudmundsson G.A., Marinosdottir G.H., von Schmalensee M. 2011. Verndun og endurreisn svartfuglastofna. A Report for the Icelandic Ministry for the Environment and Natural Resources, Reykjavik. 
Unnsteinsdottir E.R., Hersteinsson P. 2009. Surviving north of the natural range: the importance of density independence in determining population size. Journal of Zoology, 277: 232-240.

Unnsteinsdottir E.R., Hersteinsson P., Palsson S., Angerbjorn A. 2016. The fall and rise of the Icelandic Arctic fox (Vulpes lagopus): a 50year demographic study on a noncyclic Arctic fox population. Oecologia, 181: 1129-1138.

von Schmalensee M. 2010. Ecosystems in peril, part two: Alien and invasive species in Iceland. Natturufraedingurinn, 80: 84-102.

von Schmalensee M., Skarphedinsson L.H., Vesteinsdottir H., Gunnarsson T.G., Hersteinsson P., Arnthorsdottir A.L., Arnardottir H., Hauksson S.B. 2013. Vernd, velferd og veidar villtra fugla og spendyra. Lagaleg og stjornsysluleg stada og tillogur um urbaetur. A Report to the Minister for the Environment and Natural Resources. 350 pp. + appendices.

Cite as: Stefansson R.A., von Schmalensee M., Skorupski J. 2016. A tale of conquest and crisis: invasion history and status of the American mink (Neovison vison) in Iceland. Acta Biologica, 23: 87-100. DOI: 10.18276/ab.2016.23-08. 